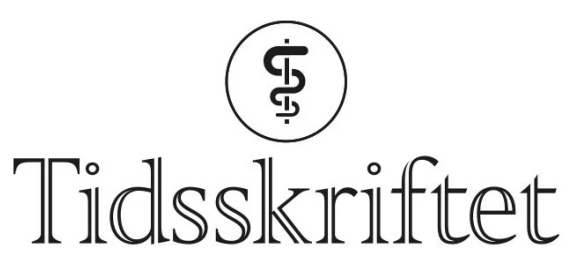

DEN NORSKE LEGEFORENING

\title{
Cerebral venetrombose etter covid-19
}

\author{
KORT KASUISTIKK
}

LARS TVEIT

latvei@ous-hf.no

Nevrologisk avdeling

Oslo universitetssykehus

Lars Tveit er lege i spesialisering.

Forfatteren har fylt ut ICMJE-skjemaet og oppgir ingen interessekonflikter.

\section{BRIAN ENRIQUEZ}

Nevrologisk avdeling

Oslo universitetssykehus

Brian Enriquez er overlege.

Forfatteren har fylt ut ICMJE-skjemaet og oppgir ingen interessekonflikter.

\section{BJØRN TENNØE}

Avdeling for radiologi og nukleærmedisin

Oslo universitetssykehus

Bjørn Tennøe er overlege.

Forfatteren har fylt ut ICMJE-skjemaet og oppgir ingen interessekonflikter.

\section{BOGNA WARSZA}

Avdeling for radiologi og nukleærmedisin

Oslo universitetssykehus

Bogna Warsza er lege i spesialisering.

Forfatteren har fylt ut ICMJE-skjemaet og oppgir ingen interessekonflikter.

\section{LARS JØRGEN GARSTAD}

Nevrologisk avdeling

Sørlandet sykehus

Lars Jørgen Garstad er lege i spesialisering.

Forfatteren har fylt ut ICMJE-skjemaet og oppgir ingen interessekonflikter.

\section{MARTIN WEISSHAAR}

Nevrologisk avdeling

Sørlandet sykehus

Martin Weisshaar er overlege.

Forfatteren har fylt ut ICMJE-skjemaet og oppgir ingen interessekonflikter.

ANNE HEGE AAMODT

Nevrologisk avdeling 


\section{Under covid-19-pandemien kommer det stadig flere rapporter om hjerneslag hos smittede. Vi presenterer her en pasient med cerebral venetrombose i etterkant av covid-19. Cerebral venetrombose er en sjelden årsak til hjerneslag og kan gi svært ulike symptomer.}

En tidligere frisk mann i 5o-årene ble innlagt i nevrologisk avdeling ved sitt lokalsykehus grunnet forvirring og redusert bevissthet.

En måned tidligere hadde pasienten fått hodepine, etterfulgt av feber fire dager senere. Han utviklet samtidig lett tørrhoste, diaré og oppkast samt svekket smak- og luktesans. Det ble påvist SARS-CoV-2 i øvre luftveier, og pasienten ble diagnostisert med covid-19. Han var sengeliggende med sterk hodepine og hadde vanskeligheter med å ta til seg mat og drikke. Han benyttet analgetika i form av paracetamol og ibuprofen. Han var først feberfri etter ti dager og returnerte til jobb tre uker etter sykdomsdebut. Han hadde da ingen hodepine. En uke senere ble han innlagt med akutt forvirring etter at han noen timer tidligere hadde vært i sin habitualtilstand. Kvelden i forveien hadde han hatt lett hodepine.

Ved innkomst fremsto han forvirret, søvnig og med afasi. CT caput avdekket intracerebral blødning i venstre temporallapp, og pasienten ble overflyttet til universitetssykehus for observasjon. Ved ankomst der var pasienten våken, men desorientert og hadde afasi uten andre fokalnevrologiske utfall. Han skåret 4 poeng på National Institutes of Health Stroke Scale, forenlig med et mindre hjerneslag. Kontroll-CT caput uten kontrast viste uendret størrelse av hjerneblødningen, og det ble reist mistanke om hemoragisk venøst infarkt grunnet tegn til cerebral venetrombose (figur 1). Supplerende CT-venografi viste manglende kontrastfylning av sinus transversus og sinus sigmoideus på venstre side, som bekreftet diagnosen (figur 2). Det ble samme dag startet behandling med lavmolekylært heparin i form av dalteparin $100 \mathrm{IE} / \mathrm{kg}$ to ganger daglig.

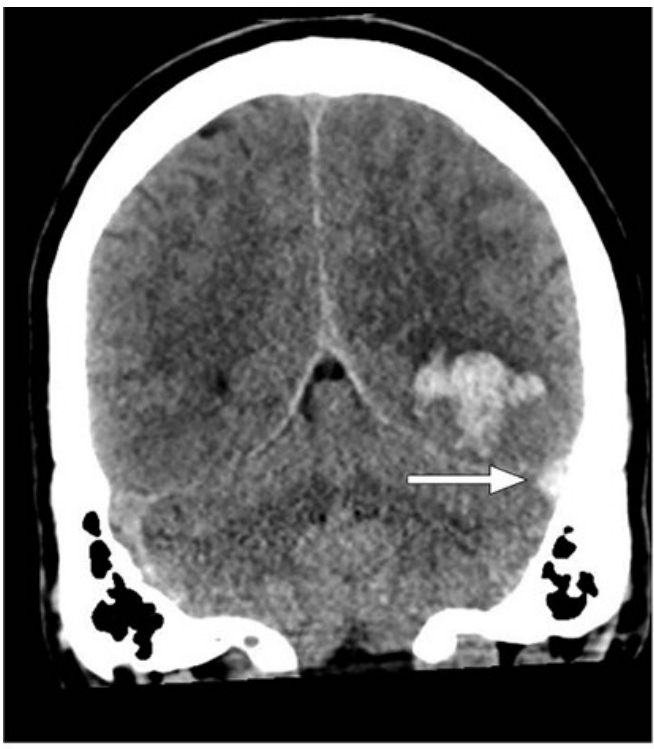

a

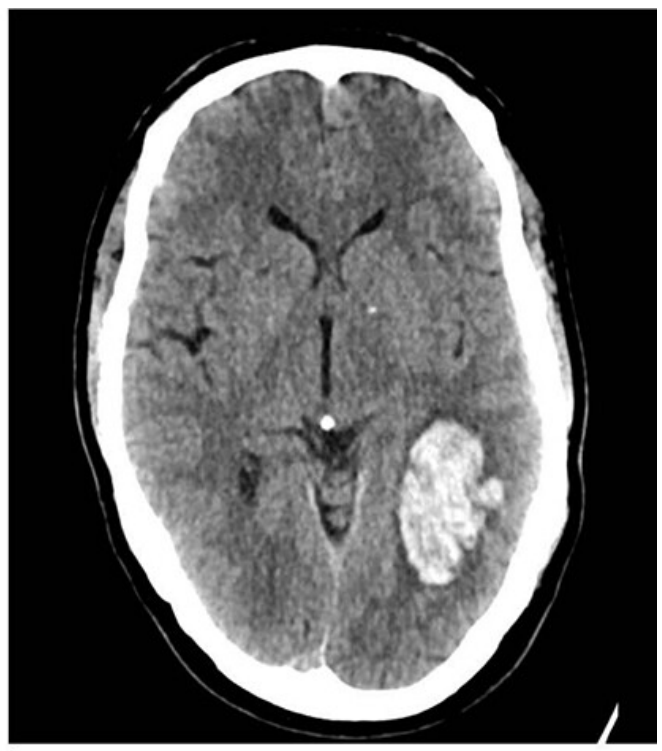

b

Figur 1 Aksial (a) og coronal (b) CT caput uten intravenøs kontrast viser intracerebralt hematom i venstre temporallapp med moderat omkringliggende ødem. Sinus transversus på venstre side er hyperdens (pil), et tegn som gir mistanke om sinusvenetrombose. 
Hematom i denne lokalisasjonen kan tyde på hemoragisk venøst infarkt, sekundært til trombose i sinus transversus.

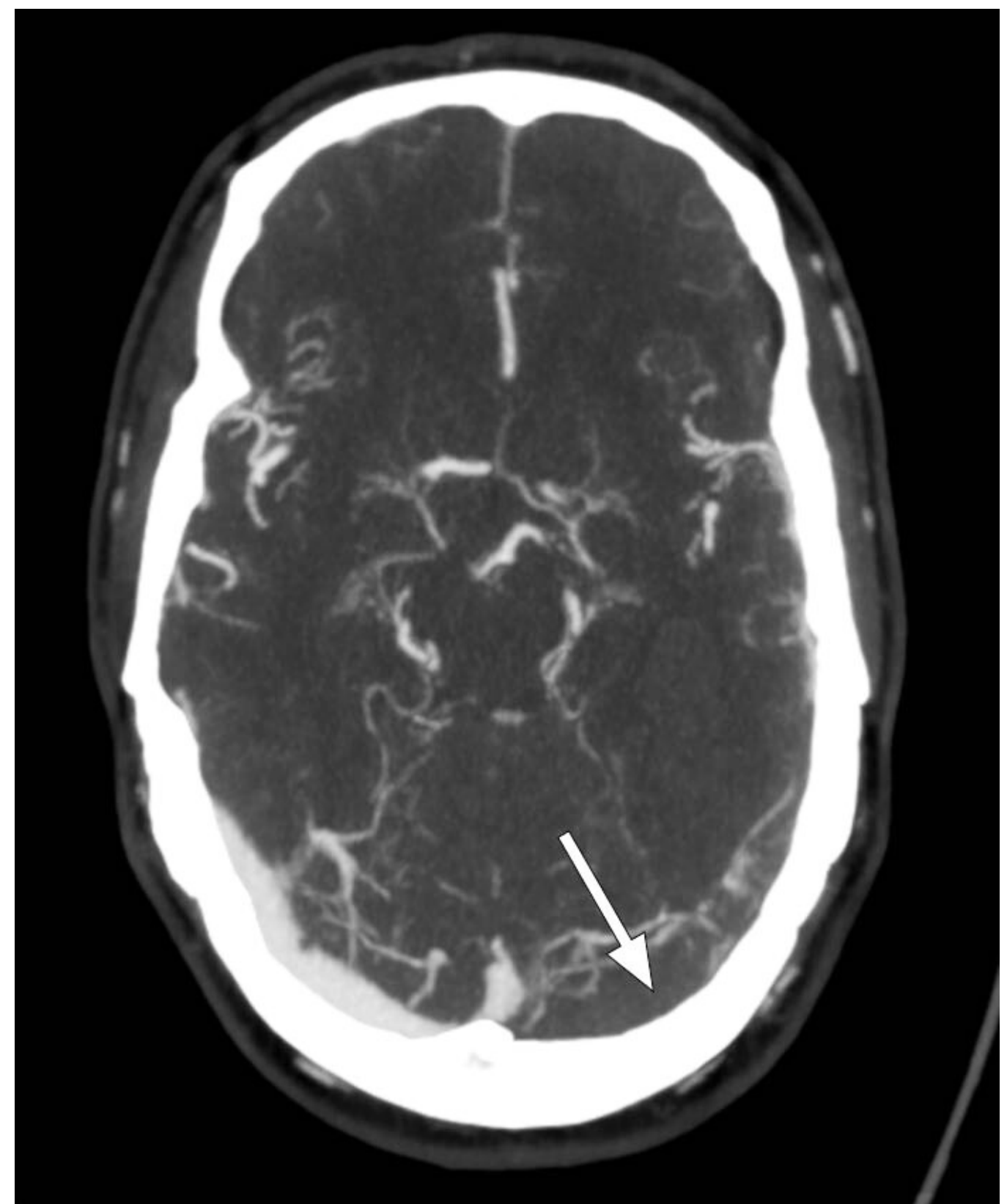

Figur 2 Aksial kontrastforsterket CT-venografi viser manglende kontrastfylning i venstre sinus transversus (pil), forenlig med sinusvenetrombose.

Pasienten ble senere overflyttet til lokalsykehus. Ved utskrivning til rehabiliteringsopphold hadde han lettere afasi med benevningsvansker, en homonym høyresidig øvre kvadrantanopsi og hukommelsesvansker.

Pasienten hadde ikke tidligere hatt arterielle eller venøse tromboser, benyttet ingen faste medisiner, hadde aldri røkt og det var ingen kjente tilfeller av venetrombose hos førstegradsslektninger. Han var overvektig, med BMI>30. Utredning med CT thorax/abdomen/bekken gav ikke holdepunkter for malign sykdom. Undersøkelser med tanke på arvelig og ervervet trombosetendens (faktor V-Leiden-mutasjon, protrombinmutasjon, protein S-antigen, protein C-aktivitet, fosfolipidantistoffer) viste normale funn.

Ved siste kontakt fire måneder etter innleggelse hadde pasienten hatt stor fremgang. Han hadde ingen språkvansker, ingen motoriske sekveler og var selvhjulpen i det daglige.

Pasient og pårørende beskrev lettere svekket korttidshukommelse samt konsentrasjonsvansker.

\section{Diskusjon}


Cerebral venetrombose er en sjelden form for venøs tromboembolisme og rammer hjernens vener og venesinus. Insidensen er i senere studier beregnet til 1,3-1,6/100 ooo/år (1, 2). Cerebral venetrombose kan gi økt intrakranialt trykk grunnet trombose i større venesinus og påfølgende svekket drenasje av cerebrospinalvæske samt venøs stase med ødemutvikling og venøse infarkter (3). Man anslår at cerebral venetrombose er årsaken til om lag $0,5 \%$ av alle hjerneslag (4).

Sykdommen forekommer i alle aldre, men er vanligst blant yngre pasienter og hos kvinner (5). Ulike risikofaktorer er assosiert med tilstanden, blant annet infeksjon, kreftsykdom, trombofili, inflammatoriske sykdommer, svangerskap og en rekke medikamenter $(3,5, \underline{6})$. Intracerebral blødning forekommer ved diagnosetidspunkt hos $30-40 \%$ av pasientene ( $\underline{6}$ ). Cerebral venetrombose kan gi svært ulike symptomer og avhenger blant annet av trombelokalisasjon $(3, \underline{6})$. Hodepine er et hyppig symptom og ses hos nær $90 \%$ (5). Epileptiske anfall forekommer hos rundt $40 \%$ (ㅁ) . Ved venøse infarkter er afasi og hemiparese vanlige symptomer (므). Trombose i det dypere venesystemet kan gi bilaterale thalamusinfarkter, med påfølgende bevissthetssvekkelse (3).

Cerebral venetrombose diagnostiseres med CT- eller MR-angiografi med venefase ( $\underline{6})$. Korrekt diagnose er vesentlig, da antikoagulasjonsbehandling er indisert i akuttfasen, også ved tilstedeværelse av intracerebral blødning $(\underline{6}, 7.7)$. Antikoagulasjonsbehandling kan hindre ytterligere trombosering som ligger til grunn for blødning i det venøse infarktet. I europeiske retningslinjer anbefales initial behandling med lavmolekylært heparin fremfor ufraksjonert heparin (7.). Hos pasienter med nyresvikt eller ved ønske om mulighet for rask reversering av antikoagulasjonseffekt foretrekkes ufraksjonert heparin (7.). Man anbefaler 3-12 måneders antikoagulasjonsbehandling med vitamin K-antagonist i etterkant av en cerebral venetrombose $(\underline{6}, 7$.$) . Ved erkjent forbigående utløsende årsak foreslås 3-$ 6 måneders behandling. Ved residiverende venøs tromboembolisk sykdom eller alvorlig trombofili kan man vurdere antikoagulasjonsbehandling på ubestemt tid.

Coronavirus disease 2019 (covid-19) ble av Verdens helseorganisasjon 11. mars 2020 erklært en verdensomspennende pandemi $(\underline{8})$. I etterkant har det vært stadige rapporter om tilfeller med affeksjon av nervesystemet ved covid-19. I en studie av hospitaliserte pasienter med covid-19 fant man nevrologiske manifestasjoner hos en av tre pasienter (9). Av pasienter med alvorlig infeksjon (etter et kriteriebasert system) fikk 5,7 \% hjerneslag (9.). I mindre pasientserier er det beskrevet hjerneslag som et tidlig symptom ved covid-19 (므) samt hjerneinfarkt grunnet storkarokklusjon hos pasienter både over og under 50 år $(\underline{11}, \underline{12})$.

Et fremtredende trekk ved alvorlig covid-19 er aktivering av koagulasjonssystemet $(13,14)$, som kan føre til arteriell og venøs tromboembolisk sykdom $(15,16)$. Det er ikke endelig avklart i hvilken grad venøs trombose skyldes spesifikke sykdomsmekanismer ved covid-19 eller faktorer som også sees ved annen infeksjonssykdom. Men det er økende holdepunkter for at pasienter med covid-19 er spesielt utsatt, særlig de med alvorlig sykdom (16-19). I flere kasusrapporter er det meldt om cerebral venetrombose hos pasienter med covid-19 (20-24). Det er publisert internasjonale retningslinjer som omhandler tromboseprofylakse ved covid-19 (1ㅡ), og en norsk gruppe har også nylig kommet med anbefalinger om profylakse og behandling (17.). Begge anbefaler liberal bruk av tromboseprofylakse til inneliggende pasienter.

Vår pasient hadde i utgangpunktet lav risiko for venøs tromboembolisk sykdom. Foruten overvekt hadde han ingen kjente risikofaktorer, og underliggende trombosetendens ble heller ikke avdekket. Ettersom det er sannsynlig at pasienter med covid-19 har $\emptyset$ kt risiko for venetrombose, mener vi det initiale sykdomsforløpet med covid-19 hos vår pasient var årsak til hans cerebrale venetrombose.

Kasuistikken viser et tilfelle av alvorlig hjernesykdom hos en pasient med et initialt mildere forløp av covid-19. I tillegg illustreres viktigheten av differensialdiagnostikk ved hjerneblødning. 
Pasienten har gitt samtykke til at artikkelen blir publisert.

Artikkelen er fagfellevurdert.

\section{LITTERATUR}

1. Coutinho JM, Zuurbier SM, Aramideh M et al. The incidence of cerebral venous thrombosis: a crosssectional study. Stroke 2012; 43: 3375-7. [PubMed][CrossRef]

2. Devasagayam S, Wyatt B, Leyden J et al. Cerebral venous sinus thrombosis incidence is higher than previously thought: A retrospective population-based study. Stroke 2016; 47: 2180-2. [PubMed] [CrossRef]

3. Stam J. Thrombosis of the cerebral veins and sinuses. N Engl J Med 2005;352: 1791-8. [PubMed] [CrossRef]

4. Bousser MG, Crassard I. Cerebral venous thrombosis, pregnancy and oral contraceptives. Thromb Res 2012; 130 (suppl 1): S19-22. [PubMed][CrossRef]

5. Ferro JM, Canhão P, Stam J et al. Prognosis of cerebral vein and dural sinus thrombosis: results of the International Study on Cerebral Vein and Dural Sinus Thrombosis (ISCVT). Stroke 2004; 35: 66470. [PubMed][CrossRef]

6. Saposnik G, Barinagarrementeria F, Brown RD et al. Diagnosis and management of cerebral venous thrombosis: a statement for healthcare professionals from the American Heart Association/American Stroke Association. Stroke 2011; 42: 1158-92. [PubMed][CrossRef]

7. Ferro JM, Bousser MG, Canhão P et al. European Stroke Organization guideline for the diagnosis and treatment of cerebral venous thrombosis - endorsed by the European Academy of Neurology. Eur J Neurol 2017; 24: 1203-13. [PubMed][CrossRef]

8. WHO Director-General's opening remarks at the media briefing on COVID-19-11 March 2020. https://www.who.int/dg/speeches/detail/who-director-general-s-opening-remarks-at-the-mediabriefing-on-covid-19---11-march-2020 Lest 9.11.2020.

9. Mao L, Jin H, Wang M et al. Neurologic manifestations of hospitalized patients with coronavirus disease 2019 in Wuhan, China. JAMA Neurol 2020; 77: 683-90. [PubMed][CrossRef]

10. Avula A, Nalleballe K, Narula N et al. COVID-19 presenting as stroke. Brain Behav Immun 2020; 87: 115-9. [PubMed][CrossRef]

11. Beyrouti R, Adams ME, Benjamin L et al. Characteristics of ischaemic stroke associated with COVID-19. J Neurol Neurosurg Psychiatry 2020; 91: 889-91. [PubMed][CrossRef]

12. Oxley TJ, Mocco J, Majidi S et al. Large-vessel stroke as a presenting feature of covid-19 in the young. N Engl J Med 2020; 382: e6o. [PubMed][CrossRef]

13. Tang N, Li D, Wang X et al. Abnormal coagulation parameters are associated with poor prognosis in patients with novel coronavirus pneumonia. JThromb Haemost 2020; 18: 844-7. [PubMed] [CrossRef]

14. Zhou F, Yu T, Du R et al. Clinical course and risk factors for mortality of adult inpatients with COVID-19 in Wuhan, China: a retrospective cohort study. Lancet 2020;395:1054-62. [PubMed] [CrossRef]

15. Zubair AS, McAlpine LS, Gardin T et al. Neuropathogenesis and neurologic manifestations of the coronaviruses in the age of coronavirus disease 2019: A review. JAMA Neurol 2020; 77: 1018-27. [PubMed][CrossRef]

16. Klok FA, Kruip MJHA, van der Meer NJM et al. Incidence of thrombotic complications in critically ill ICU patients with COVID-19. Thromb Res 2020; 191:145-7. [PubMed][CrossRef]

17. Kvåle R, Azrakhsh NA, Mohn KG et al. Covid-19 og venøs tromboembolisme - profylakse og behandling. Tidsskr Nor Legeforen 2020; 140. doi: 10.4045/tidsskr.20.0440. [PubMed][CrossRef]

18. Barnes GD, Burnett A, Allen A et al. Thromboembolism and anticoagulant therapy during the COVID-19 pandemic: interim clinical guidance from the anticoagulation forum. JThromb Thrombolysis 2020; 50: 72-81. [PubMed][CrossRef]

19. Tveita A, Hestenes S, Sporastøyl ER et al. Lungeembolisme ved covid-19. Tidsskr Nor Legeforen 2020; 140. doi: 10.4045/tidsskr.20.0366. [PubMed][CrossRef]

20. Hughes C, Nichols T, Pike M et al. Cerebral venous sinus thrombosis as a presentation of COVID19. Eur J Case Rep Intern Med 2020; 7: 001691. [PubMed]

21. Garaci F, Di Giuliano F, Picchi E et al. Venous cerebral thrombosis in COVID-19 patient. J Neurol Sci 2020; 414: 116871. [PubMed][CrossRef] 
22. Hemasian H, Ansari B. First case of Covid-19 presented with cerebral venous thrombosis: A rare and dreaded case. Rev Neurol (Paris) 2020; 176: 521-3. [PubMed][CrossRef]

23. Klein DE, Libman R, Kirsch C et al. Cerebral venous thrombosis: A typical presentation of COVID19 in the young. J Stroke Cerebrovasc Dis 2020; 29:104989. [PubMed][CrossRef]

24. Cavalcanti DD, Raz E, Shapiro M et al. Cerebral venous thrombosis associated with COVID-19. AJNR Am J Neuroradiol 2020; 41: 1370-6. [PubMed][CrossRef]

Publisert: 14. desember 2020. Tidsskr Nor Legeforen. DOI: 10.4045/tidsskr.20.0563

Mottatt 29.1.2020, første revisjon innsendt 28.9.2020, godkjent 9.11.2020.

Publisert under åpen tilgang CC BY-ND. Lastet ned fra tidsskriftet.no 26. april 2023. 